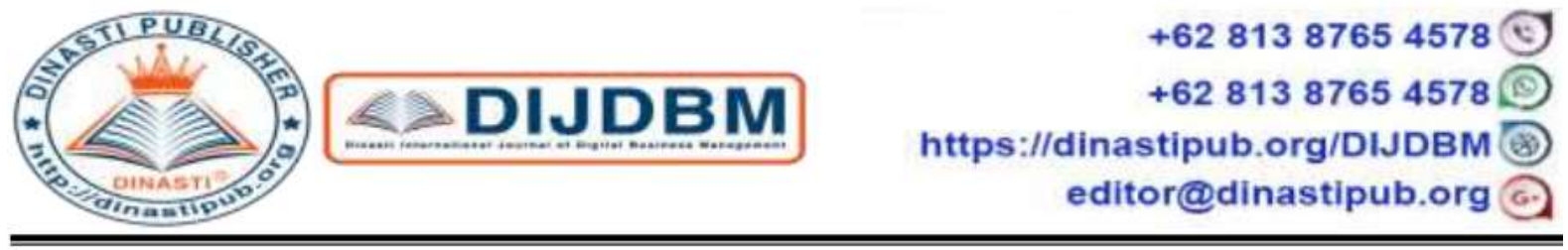

THE EFFECT OF DER, TATO, ROA AND SHARE PRICE TO PBV (Studies on the food and beverage industry on the Indonesia Stock Exchange period of 2012-2018)

\title{
Iwan Firdaus
}

Undergraduate Program, Department of Managent, Faculty of Economics and Business Mercu Buana University, Indonesia

\begin{tabular}{|c|c|}
\hline $\begin{array}{l}\text { ARTICLE INFORMATION } \\
\text { Received: } 30 \text { January } 2020 \\
\text { Revised: } 5 \text { February } 2020 \\
\text { Issued: } 20 \text { February } 2020 \\
\text { (filled in by Editor) } \\
\text { Corresponding author: first author } \\
\text { E-mail: } \\
\text { iwanfirdaus08179@ gmail.com }\end{array}$ & $\begin{array}{l}\text { Abstract: This research is to find out the influence of } \\
\text { DER, TATO, ROA and Share Price to PBV on } \\
\text { companies listed in Indonesia Stock Exchange retail } \\
\text { sub sector ffod and beverage period 2012-2019. The } \\
\text { sample selection in this research using saturated } \\
\text { sampling method and got } 7 \text { companies that match the } \\
\text { criteria, so that } 49 \text { data were obtained. The research } \\
\text { data is obtained from Indonesia Stock Exchange. The } \\
\text { method used in this research is panel data multiple } \\
\text { regression analysis and it is found that the more } \\
\text { appropriate model used is fixed effect. From result of } \\
\text { research got value of adjusted R-Square equal to } \\
79,12 \% \text {. Partially show that DER have negative and } \\
\text { significant effect to PBV. TATO, Share Price } \\
\text { variable partially had positive and significant effect } \\
\text { to PBV. ROA variable partially have positive and no } \\
\text { significant effect to PBV. } \\
\text { Keywords: DER, TATO, ROA, Share Price, and PBV }\end{array}$ \\
\hline
\end{tabular}

\section{INTRODUCTION}

The food and beverage industry is expected to grow stagnant the same as last year. The influence of the United States Dollar (US) on the Rupiah makes the main driver of stagnant growth factors in the past few years. According to (Lukman.2019) General Chair of the Indonesian Food and Beverage Entrepreneurs Association (Gapmmi), in (kontan.co.id, 2019) in addition to the US Dollar, the issue of Provincial Drinking Wages (UMP) also affects the growth of the food and beverage industry this year. Besides, the increase in fuel subsidies planned by the government according to Gapmmi will affect the food and beverage industry. Transportation of the distribution of goods (raw materials and finished goods) uses subsidized fuel.

According to (Lukman.2019), if subsidized fuel is reduced or removed it certainly affects logical sales. This means whether this logistics or transportation or distribution will rise or not will wait from the transportation sector. (Lukman.2019) estimates, the food, and beverage industry in this political year will experience growth of around $8 \%$ to $9 \%$ or 
stagnant. Drink, snack and biscuit products will dominate the campaign both in national and regional elections.

On another occasion, the Ministry of Industry set a growth target for the agro-industry sector by $7.10 \%$ in 2019 , higher than last year's achievement of $6.93 \%$. The performance of the agro-industry sector is projected to be boosted due to a surge in domestic demand in the general election momentum, such as food and beverage products. Acting Director-General of Agro-Industry Ministry of Industry Achmad Sigit Dwiwahjono explained that in this political year, several sectors will seize great opportunities, including the food and beverage industry. In the third quarter of 2018, the agro-industry recorded an annual growth of $7.23 \%$. "We are optimistic that the realization of the growth of the agro-industry in 2019 will be greater than the target of $7.10 \%$," he added in a press statement on Sunday (1/6). Especially the food and beverage industry is believed to grow by $9.86 \%$ in 2019 .

In line with the Ministry of Industry, according to (Suratmo, 2019) Deputy Head of the Indonesian Food and Beverage Entrepreneurs Association (GAPMMI) in (kontan.co.id, 2019) said that this year the growth of the food and beverage industry will stabilize to grow $8 \%$ to $9 \%$. This is adjusted to the economic conditions and purchasing power of Indonesian people which is predicted to be still the same as last year. It's just that this year there are new challenges namely the difficulty of raw materials, such as coconut because of many coconutproducing areas that have recently been affected by the disaster. But for other raw materials such as flour, according to him, is still controlled and assisted by imports. Public purchasing power is believed to increase again after the national election is held.

The following researchers attach PBV table data from 7 banking companies listed on the Indonesia Stock Exchange in 2012-2018:

Table 1. Table of PBV

\begin{tabular}{cccccccc}
\hline Companies & 2012 & 2013 & 2014 & 2015 & 2016 & 2017 & 2018 \\
\hline CEKA & 1,90 & 2,32 & 3,00 & 2,70 & 5,40 & 5,16 & 5,50 \\
INDF & 1,50 & 1,51 & 1,44 & 1,05 & 1,55 & 1,43 & 1,35 \\
MYOR & 1,37 & 2,08 & 1,67 & 2,44 & 3,29 & 4,04 & 5,24 \\
ROTI & 1,08 & 0,80 & 1,09 & 0,99 & 1,25 & 1,00 & 0,94 \\
SKBM & 2,60 & 2,07 & 2,86 & 2,57 & 1,65 & 1,23 & 1,15 \\
SKLT & 0,96 & 0,89 & 1,35 & 1,68 & 1,27 & 2,46 & 3,16 \\
ULTJ & 2,29 & 6,45 & 4,74 & 4,07 & 3,95 & 3,59 & 3,32 \\
\hline Average & 1,67 & 2,30 & 2,31 & 2,21 & 2,62 & 2,70 & 2,95 \\
\hline
\end{tabular}

Source: IDX data processed, 2019

Based on table 1 PBV of the food and beverage industry listed on the Indonesia Stock Exchange in 2012-2018, it appears that industrially, almost all of the PBV data distribution is below number 2, this means the Share Prices for the food and beverage industry listed on the Indonesia Stock Exchange in 2012-2018 at low value. PBV value below number 2 means that the share price cannot be higher than the book value of the stock. It can be said that the Share Prices for the food and beverage industry listed on the Indonesia Stock Exchange in 20122018 are still considered cheap. 


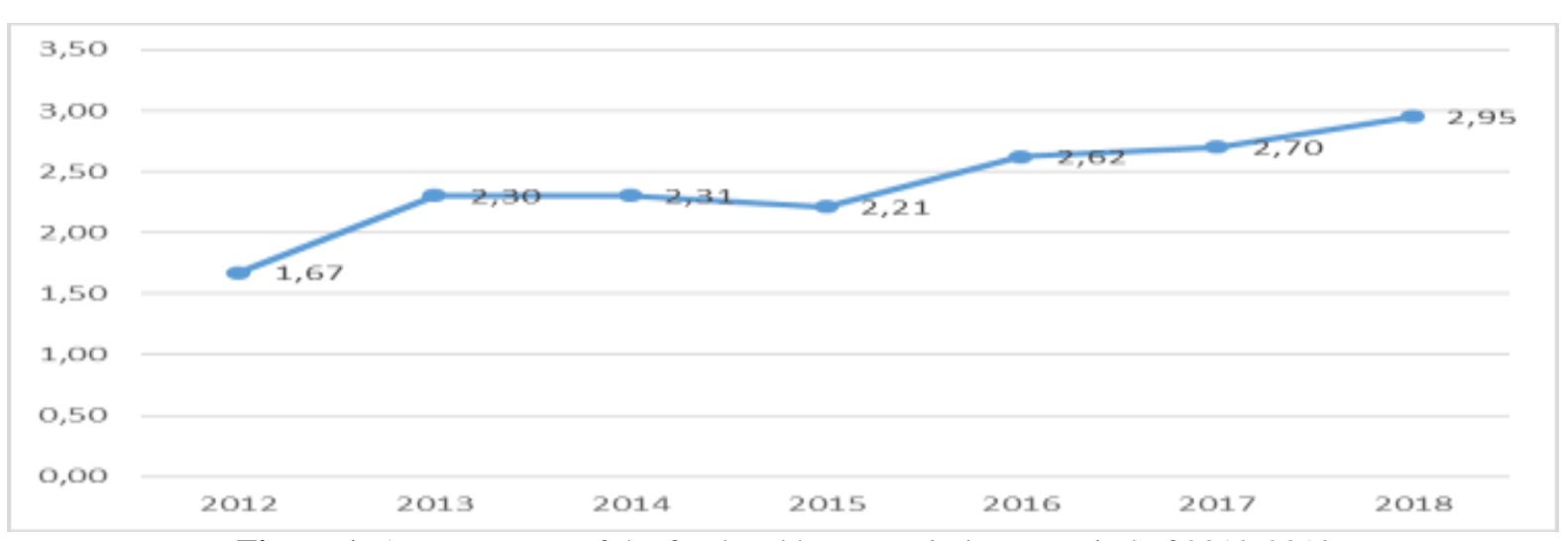

Figure 1. Average PBV of the food and beverage industry period of 2012-2018

Source: IDX data processed, 2019

Based on Figure 1, the average PBV of the food and beverage industry listed on the Indonesia Stock Exchange in 2012-2018 seems to be rising slowly every year, although the average PBV is above 2, the increase per year is very slow from 2014 to 2018 the increase is only $2 \%$ to $2.9 \%$. This slowdown was due to various obstacles such as the exchange rate of the Rupiah against the United States Dollar (US), the increase in the Provincial Minimum Wage (UMP) and the plan to eliminate subsidized fuel, making food and beverage issuers have to review the prices of their products. According to the General Chair of the Indonesian Food and Beverage Entrepreneurs Association (Lukman, 2019) in (Kontan.co.id, Jakarta, 2019), price increases are estimated to be between $3 \%$ to $5 \%$, because the food and beverage industry is affected by inflation.

Research on company value calculated by price-book value (PBV), has been widely carried out by previous researchers. Different research results indicate a research gap regarding the effect of the level of profitability, investment decisions and funding decisions on firm value.

According to research conducted by (Languju, et al, 2016), (Rinnaya, et al, 2016), (Utomo, A, U, 2016), (Kushartono, R, C, 2017), (Misran, M and Chabachib, M, 2017), (Utami, R, A and Prasetiono, 2017), (Pasando, V, 2018), (Routine, et al, 2019), (Sari, et al, 2019), (Utami, P and Welas, 2019) and (Apriliyanti, et al, 2019) DER has a positive and significant effect on PBV, whereas according to (Rahayu, M and Sari, B, 2018) DER has a negative and significant effect on PBV. Other research conducted by (Astutik, D, 2017) and (Sondakh, et al, 2019) DER has a positive but not significant effect on PBV with other sentences DER does not affect PBV, then according to (Sutrisno, W, A and Yulianeu, 2017 ), (Widodo, A, 2018) and (Nur'aidawati, S, 2018) DER has a negative but not significant effect on PBV, with other sentences DER does not affect PBV.

Research conducted by (Rinnaya, et al, 2016) and (Misran, M and Chabachib, M, 2017 TATO has a positive and significant effect on PBV, whereas according to (Kushartono, R, C, 2017) TATO has a negative and significant effect on PBV. Other research conducted by (Sutrisno, W, A and Yulianeu, 2017), (Utami, R, A and Prasetiono, 2017), (Widodo, A, 2018), (Pasando, V, 2018), (Nur'aidawati, S, 2018), (Routine, et al, 2019), (Sari, et al, 2019) and (Utami, P and Welas, 2019) and (Sondakh, et al, 2019) TATO has a positive but not 
significant effect on PBV with other sentences TATO has no effect on PBV, and then according to (Astutik, D, 2017), TATO has a negative but not significant effect on PBV, with other sentences TATO has no effect on PBV.

Research conducted by (Rinnaya, et al, 2016), (Utomo, A, U, 2016), (Astutik, D, 2017), (Kushartono, R, C, 2017), (Misran, M and Chabachib, M, 2017), (Sutrisno, W, A and Yulianeu, 2017), (Utami, R, A and Prasetiono, 2017), (Putra, R, A, 2018), (Nur'aidawati, S, 2018), (Routine, et al, 2019), (Sari, et al, 2019) and (Apriliyanti, et al, 2019) ROA has a positive and significant effect on PBV, whereas according to (Widodo, A, 2018) and (Pasando, V, 2018) ROA has an effect positive but not significant to PBV with other sentences ROA has no effect on PBV.

Research conducted by (Putra, R, A, 2018) and (Kurnia, D, 2018) Share Prices have a positive and significant effect on PBV. Based on several phenomena and the results of the research gap described above, it appears that research in the banking sector is still small with the PBV approach, so researchers are interested in researching with the title: Effect of DER, TATO, ROA and Share Prices on PBV in the food industry and beverages that are Listed on the Indonesia Stock Exchange for the 2012-2018 Period.

1. Based on the above background, the problems in this study are formulated in the following research questions: Does DER affect the PBV in the food and beverage industry listed on the Indonesia Stock Exchange in 2012-2018?

2. Does TATO influence the PBV in the food and beverage industry listed on the Indonesia Stock Exchange in 2012-2018?

3. Does ROA affect the PBV in the food and beverage industry listed on the Indonesia Stock Exchange in 2012-2018?

4. Does the Share Price affect the PBV in the food and beverage industry listed on the Indonesia Stock Exchange in 2012-2018?

\section{RESEARCH PURPOSES}

The objectives of this research are:

1. To find out and analyze the effect of DER on PBV in the food and beverage industry listed on the Indonesia Stock Exchange in 2012-2018.

2. To find out and analyze the effect of TATO on PBV in the food and beverage industry listed on the Indonesia Stock Exchange in 2012-2018.

3. To find out and analyze the effect of ROA on PBV in the food and beverage industry listed on the Indonesia Stock Exchange in 2012-2018.

4. To find out and analyze the effect of Share Prices on PBV in the food and beverage industry which is listed on the Indonesia Stock Exchange in 2012-2018.

\section{RESEARCH CONTRIBUTION}

\section{Practical Contributions}

The results of research on the effect of DER, TATO, ROA, and Share Prices on PBV in the food and beverage industry listed on the Indonesia Stock Exchange for the 2012-2018 period are expected to become one of the studies and references in the field of Management and can be published in international scientific journals.

2. Theoretical Contributions 
The results of this study are expected to provide understanding, knowledge, and information about PBV in the food and beverage industry listed on the Indonesia Stock Exchange (BEI) in 2012-2018 and can be taken into consideration for other academic practitioners.

\section{LITERATURE REVIEW}

\section{Financial Management}

According to (Brigham and Houston, 2019) financial management is an art and science, which regulates money, through processes, institutions/institutions, markets, and instruments that are involved with money transfer issues between individuals, businesses, and governments

\section{Investment Theory}

According to (Fahmi, 2014) the effect of the government budget (government budget) on economic growth is to be able to enlarge the expenditure budget in a sluggish economy so that employment increases and ultimately will increase people's income. Changes that occur due to government spending will affect the increase in national income, referred to as a multiplier process. To achieve effectiveness and efficiency in investment decisions we need to set goals to be achieved, namely: (1) The creation of continuity in investment. (2) The creation of maximum profit. (3) Creating prosperity for shareholders. (4) Contribute to national development.

\section{Shares}

According to (Ross et al., 2015) shares are defined as a sign of ownership or ownership of a person or entity in a company or limited liability company. According to (Brigham and Houston, 2019) shares are divided into 2 types: (1) Common shares. Common stock is the stock that places the most junior owner of the distribution of dividends, and the rights to the company's assets if the company is bankrupt. (2) Preferred stock. Preferred shares are shares that have rights over ordinary shares, such as prioritized rights in dividend payments.

\section{Price to book value ratio (PBV)}

Company value describes certain conditions that have been achieved by a company as a form of community trust in the company after going through a process of activities for several years since the company was founded until now. According to (Ross et al., 2015) Price to book value ratio or PBV can be calculated using the following formula:

$$
\mathrm{PBV}=\text { market value / book value }
$$

\section{Debt to Equity Ratio (DER)}

According to (Brigham and Houston, 2019) this ratio measures how far the company uses funding through debt. By using debt, investors can maintain control of the company. On the other hand creditors will see equity as a security limitation, so the higher the equity the less creditor risk. In this study the leverage ratio used is Debt to Equity Ratio (DER). According to (Martin, 2014) the relationship between debt and equity is often used to examine 
the problem of financing. According to (Dewi and Wirajaya, 2013) the determination of capital structure using debt at a certain level (as far as greater benefits, additional debt is still permitted) as a source of funding can increase profitability and corporate value. The higher the DER, the greater the risk faced and investors will ask for a higher level of profit. The ratio is stated in the formula:

$$
\text { DER = Total Debt } / \text { Total Equity }
$$

\section{Total Asset Turn Over (TATO)}

According to (Brigham and Houston, 2019) this ratio is used to measure how efficient all company assets are used to support sales activities. If a company can sell using minimal assets, it will produce a higher asset turnover ratio while a low asset turnover ratio shows that the company is using its assets inefficiently and optimally, according to (Ross et al., 2015) to find total assets turn over as follows:

$$
\text { TATO }=\text { Sales } / \text { Total Assets }
$$

\section{Return on Assets (ROA)}

According to (Brigham and Houston, 2019) is the final result of a number of company management policies and decisions. In the study of the ratio used Return On Assets (ROA). Low ROA is a result of the ability to generate low corporate profits, as well as high interest costs from the use of debt. (Brigham and Houston, 2019), a smaller ROA than the industry average, indicates the company did not produce enough business volume, when viewed from the total investment for assets. According to (Nurhayati, 2014) profitability has a positive and significant effect on firm value. According to (Brigham and Houston, 2019):

$$
\mathrm{ROA}=\text { net income } / \text { total assets }
$$

\section{Share Price}

Share prices according to (Tandelilin, 2010) are a reflection of investors' expectations of earnings factors, cash flow and the level of return required by investors, which are also influenced by macroeconomic performance. According to (Brigham and Houston, 2019) the price of a stock is the price of a stock that occurs in the stock market at a certain time determined by market participants and is determined by the demand and supply of the relevant shares in the capital market. According to (Keown, 2014) there are several concepts about the value of a Share Price, namely:

1. The nominal value is the value listed on the stock sheet, this nominal value does not measure the real value of a stock but is the value used to determine the amount of paid-up capital reported on the company's balance sheet.

2. Book value is a value that shows the net asset value per share owned by shareholders. Book value per sheet can be obtained by distributing the total value of equity with the number of shares outstanding.

3. Market value (market value) is the value of a stock that is determined by demand and supply of shares on a stock exchange. This market value determines the size of the individual Share Price index and the Composite Share Price Index (CSPI).

4. Fundamental value or intrinsic value (intrinsic value) is the fair value or price of a stock that reflects its real value. The intrinsic value used by investors to evaluate their shares is to 
compare the intrinsic value with market value can be known whether the stock has been overpriced or still underpriced.

\section{Share Price analysis}

1. According to (Husnan, 2015) several approaches can be used to assess the price of stock but the following two approaches are the most widely used, namely: The traditional approach, to analyze stock securities with the traditional approach used two analyzes, namely:

a) Technical analysis is an analysis technique that uses data or records about the market itself to try to access the demand and supply of a particular stock or the market as a whole. This analytical approach uses published market data such as Share Prices, trading volumes, composite or individual price indices, and other technical factors. Therefore, this approach is also called the market analysis or internal analysis approach.

b) Fundamental analysis, this approach is based on an assumption that each share has intrinsic value. This intrinsic value is estimated by investors to analyze. Intrinsic value is a function of company variables that are combined to produce the expected profit and inherent risk in the stock. The intrinsic estimation results are then compared with the current market price. The stock market price is a reflection of the average intrinsic value.

2. Modern portfolio approach

The modern portfolio approach emphasizes the psychological aspects of the exchange with the assumption of a hypothesis about the exchange, namely the efficient market hypothesis. Efficient markets mean that Share Prices are reflected as a whole on all the information that is on the exchange.

\section{CONCEPTUAL FRAMEWORK}

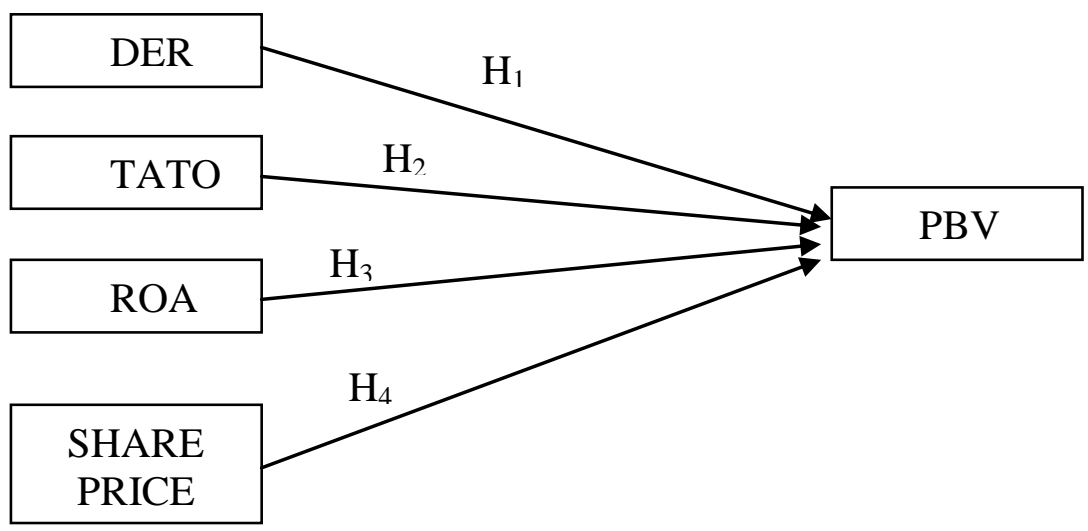

Figure 2. Conceptual Framework

Source: various sources processed, 2019

\section{HYPOTHESIS}

Based on the analysis framework above, the hypotheses of this study are:

$\mathrm{H}_{1}$ : DER has a negative influence on PBV

$\mathrm{H}_{2}$ : TATO has a positive effect on PBV

$\mathrm{H}_{3}$ : ROA has a positive effect on PBV

$\mathrm{H}_{4}$ : Share Prices have a positive influence on PBV 


\section{RESEARCH METHOD}

\section{Research design}

Causal research will analyze the effect of DER, TATO, ROA and Share Prices on PBV in the food and beverage industry listed on the Indonesia Stock Exchange for the 2012-2018 period. In causal research, researchers look for a causal relationship between two or more variables studied.

\section{Definition of variable operation}

The definition of operational variables in this study used the dependent variable and the independent variable, as follows:

1. Dependent variable

In this study, researchers used the PBV ratio-dependent variable, with the ratio measurement scale. According to (Ross et al., 2015) PBV ratio is calculated using the following formula:

$$
\mathrm{PBV}=\text { market value / book value }
$$

2. Independent variable

In this study, there are 4 (four) independent variables that are used, namely DER, TATO, ROA, and Share Prices.

a) DER

According to (Brigham and Houston, 2019), the DER ratio measures the extent to which companies use funding through debt, with a ratio measurement scale. The higher the DER, the greater the risk faced and investors will ask for a higher level of profit.

$$
\mathrm{DER}=\text { total debt } / \text { total equity }
$$

b) TATO

According to (Brigham and Houston, 2019) this ratio is used to measure how efficient all company assets are used to support sales activities:

$$
\text { TATO = Sales } / \text { Total Assets }
$$

c) ROA

According to (Brigham and Houston, 2019), ROA is used to measure the rate of return on total assets after interest expense and taxes. The formula to look for ROA is as follows:

$$
\mathrm{ROA}=\text { net income } / \text { total assets }
$$

d) Share Price

According to (Brigham and Houston, 2019) Share Price is the price of shares that occur on the stock exchange at a certain time determined by market participants and determined by the demand and supply of the relevant shares in the capital market.

\section{Population and Sample}

The population in this study are companies in the food and beverage industry which are listed on the Indonesia Stock Exchange for the 2012-2018 period, during the observation year having profit, and the data is not outlier, the total population of the study is 7 companies with 5 years of observation, so population totaling 49 data. The sampling method used is the saturated sample method, which means the number of samples is equal to the total population of the study. The number of samples was 7 companies with 5 years of observation so that the sample data amounted to 49 data. 


\section{Data collection technique}

Data collection techniques used in this study using the library (Library Research). Researchers collected data in the form of annual reports of companies in the food and beverage industry which were listed on the Indonesia Stock Exchange 2012-2018 Period.

\section{Data analysis}

This study analyzes the effect of DER, TATO, ROA and Share Prices on PBV in the food and beverage industry listed on the Indonesia Stock Exchange for the 2012-2018 period. The analytical method used is multiple linear regression analysis models on panel data, using EViews 9.0 software.

\section{DISCUSSIONS AND FINDINGS}

\section{Descriptive Statistics Results}

Table 2. Descriptive Statistics

\begin{tabular}{lccccc}
\hline \multicolumn{5}{l}{ Sample: 20122018} & \multicolumn{5}{l}{} \\
\hline Mean & PBV & DER & TATO & ROA & HRGSAHAM \\
Median & 2.395918 & 0.960816 & 1.389592 & 7.680000 & 1979.224 \\
Maximum & 1.900000 & 1.040000 & 1.240000 & 6.260000 & 1265.000 \\
Minimum & 6.450000 & 1.720000 & 3.060000 & 20.34000 & 7925.000 \\
Std. Dev. & 0.800000 & 0.190000 & 0.460000 & 0.060000 & 180.0000 \\
Skewness & 1.456102 & 0.410091 & 0.688897 & 5.211912 & 2148.763 \\
Kurtosis & 1.067846 & -0.326086 & 0.873275 & 0.683775 & 1.725757 \\
Jarque-Bera & 3.198556 & 2.215223 & 2.771644 & 2.600050 & 4.588543 \\
Probability & 9.392910 & 2.125790 & 6.334446 & 4.144894 & 29.47436 \\
Sum & 0.009128 & 0.345454 & 0.042120 & 0.125877 & 0.000000 \\
Sum Sq. Dev. & 117.4000 & 47.08000 & 68.09000 & 376.3200 & 96982.00 \\
Observations & 101.7712 & 8.072367 & 22.77979 & 1303.873 & $2.22 \mathrm{E}+08$ \\
Source: IDX & 49 & 49 & 49 & 49 & 49 \\
\hline
\end{tabular}

Source: IDX data processed by Eviews 9, 2019

Based on the results of data processing in table 4.1 above, it can be seen that $\mathrm{N}=49$, PBV has a mean value of 2.395918. Mean PBV of 2.395918 can be interpreted as a higher share price in the market of 2.395918 compared to the book value, this condition can be said to be good. The highest PBV value is 6.45 and the lowest is 0.8 . DER has a mean value of 0.960816 . Mean DER of 0.960816 can be interpreted as the company's capital structure is more sourced from equity compared to liabilities, although it is seen that equity is almost the same as equity because it is close to number 1 . The higher the DER value, the less good. The highest DER value is 1.72 and the lowest value is 0.19 . TATO has a mean value of 1.389592 . Mean TATO of 1.389592 can mean the company can increase sales by 1.389592 from utilizing the assets owned. The higher the TATO score the better. The highest TATO value is 3.06 and the lowest value is 0.46 . The share price has a mean value of 1979,224. The mean share price of 1979,224 can be interpreted quite well. The highest Share Price is 7925 and the lowest value is 180 . 


\section{RESULTS OF PANEL DATA MODEL SELECTION}

\section{Test the Fixed Effect Model}

The results of the fixed effect model test of the circumvention of data using Eviews 9.0 obtained the following results:

Table 3. Fixed Effect Model Test Results

Dependent Variable: PBV

Method: Panel Least Squares

Date: 10/14/19 Time: 18:50

Sample: 20122018

Periods included: 7

Cross-sections included: 7

Total panel (balanced) observations: 49

\begin{tabular}{|c|c|c|c|c|}
\hline Variable & Coefficient & Std. Error & $t$-Statistic & Prob. \\
\hline $\mathrm{C}$ & 0.378840 & 0.558585 & 0.678215 & 0.5017 \\
\hline DER & -0.976895 & 0.364600 & -2.679365 & 0.0108 \\
\hline TATO & 0.640237 & 0.304884 & 2.099939 & 0.0424 \\
\hline ROA & 0.051500 & 0.034217 & 1.505088 & 0.1406 \\
\hline HRGSAHAM & 0.000844 & 0.000138 & 6.134168 & 0.0000 \\
\hline \multicolumn{5}{|c|}{ Effects Specification } \\
\hline \multicolumn{5}{|c|}{ Cross-section fixed (dummy variables) } \\
\hline$R$-squared & 0.834705 & Mean dependent var & & 2.395918 \\
\hline Adjusted R-squared & 0.791206 & S.D. dependent var & & 1.456102 \\
\hline S.E. of regression & 0.665351 & Akaike info criterion & & 2.217741 \\
\hline Sum squared resid & 16.82229 & Schwarz criterion & & 2.642436 \\
\hline Log likelihood & -43.33466 & Hannan-Quinn criter. & & 2.378870 \\
\hline$F$-statistic & 19.18917 & Durbin-Watson stat & & 1.430804 \\
\hline $\operatorname{Prob}(F$-statistic $)$ & 0.000000 & & & \\
\hline
\end{tabular}

Source: IDX data processed by Eviews 9,2019

Based on table 4.2 fixed effect test results, obtained the following equation: $\mathrm{PBV}=\mathrm{C}-0.976895 \mathrm{DER}+0.640237 \mathrm{TATO}+0.05154 \mathrm{ROA}+0,000844$ Share Price Based on the results of the fixed effect model test, it appears that partially the DER, TATO, and Share Price variables affect PBV, while the ROA variable does not affect PBV. This can be seen from the probability value of the DER, TATO and Share Price variables smaller than the probability value in this study $(0.05)$. While the probability value of the variable ROA is greater than 0.05 .

\section{Hypothesis test}

T-test

Based on table 3 fixed effect model test results that contain the results of the t-test by looking at the t-statistic and probability values can be explained as follows:

\section{Effect of DER on PBV}

Based on testing table 4.2 note that the DER shows the results of $t$ count of -2.667365 and the probability value of 0.0108 . it means that the DER variable has a negative and significant effect on PBV because the probability value is smaller than 0.05 . The negative effect indicates that if the DER is high then the PBV will below and if the DER is low then 
the PBV will be high. The results of this study are in line with research (Rahayu, $M$ and Sari B, 2018).

2. The effect of TATO on PBV.

Based on testing table 4.2 note that TATO shows the results of the $t$ count of 2.099939 and the probability value of 0.04240 . it means that the TATO variable has a positive and significant effect on PBV because the probability value is smaller than 0.05 . Positive effect means that if TATO is high then PBV is also high and if TATO is low then PBV is also low. The results of this study are in line with research (Mirsan and Chabachib, 2017), (Rinnaya, et al, 2016).

3. The Effect of ROA on PBV.

Based on testing table 4.2, it is known that ROA shows the results of $t$ arithmetic of 1.505088 and the probability value of 0.1406 . it means that the ROA variable has a positive but not significant effect on PBV because the probability value is greater than 0.05 , this indicates that ROA does not affect PBV. The results of this study are in line with research (Widodo, 2018) and (Pasando, 2018).

4. The effect of Share Prices on PBV.

Based on testing table 4.2, it is known that the Share Price shows the result of a t-count of 6.134168 and the probability value of 0.0000 . it means that the Share Price variable has a positive and significant effect on PBV because the probability value is smaller than 0.05 . A positive effect means that if the Share Price is high then the PBV is also high and if the Share Price is low then the PBV is also low. The results of this study are in line with research (Putra, 2018) and (Kurnia, 2019).

\section{Coefficient of determination $\left(\mathbf{R}^{2}\right)$}

The coefficient of determination $\left(\mathrm{R}^{2}\right)$ of data processing obtained the adjusted determination coefficient test results $\left(\mathrm{R}^{2}\right)$ in table 3 the results of the fixed effect model test of $79.1206 \%$, it can be interpreted that $79.1206 \%$ of the DER, TATO, ROA, and Share Price variables can explain its relation to PBV, while the remaining $20.8794 \%$ is explained by other variables outside the study.

\section{CONCLUSION AND SUGGESTIONS}

\section{Conclusion}

Based on an analysis of the effect of DER, TATO, ROA and share prices on PBV in the food and beverage industry listed on the Indonesia Stock Exchange (BEI) in 2012-2018, the following conclusions can be drawn:

1. DER has a negative and significant effect on PBV in the food and beverage industry which is listed on the Indonesia Stock Exchange (BEI) in 2012-2018.

2. TATO has a positive and significant effect on PBV in the food and beverage industry which is listed on the Indonesia Stock Exchange (BEI) in 2012-2018.

3. ROA does not affect PBV in the food and beverage industry which is listed on the Indonesia Stock Exchange (BEI) in 2012-2018.

4. Share Prices have a positive and significant effect on PBV in the food and beverage industry which is listed on the Indonesia Stock Exchange (BEI) in 2012-2018. 


\section{Suggestion}

Based on the discussion and conclusions in this study, the following suggestions can be submitted:

1. For banking companies in Indonesia

According to the results of the study that the DER variable has a negative and significant effect on PBV in the food and beverage industry listed on the Indonesia Stock Exchange (BEI) in 2012-2018. This means companies must reduce the value of DER, by reducing the company's debt, so that the PBV of the food and beverage industry increases. Besides the company must also increase the company's TATO, by increasing the company's sales. so that the PBV of the food and beverage industry is increasing. Furthermore, the company must increase the company's Share Price by increasing the value and trust of the public so that the company's Share Price increases, so that the PBV of the food and beverage industry increases.

\section{For Investors}

Investors who invest in the food and beverage industry must pay attention to DER, TATO and the company's Share Price.

3. Share further research

Based on the Adjusted R2 value of $79.1206 \%$, it means that DER, TATO, ROA and Share Prices can explain their relationship to PBV, while the remaining $20.8794 \%$ is explained by other variables outside the research model. And it is recommended that further research add other independent variables such as ROI, sales growth, or company size.

\section{REFERENCES}

Astutik, D (2017). Pengaruh Aktivitas Rasio Keuangan Terhadap Nilai Perusahaan (Studi Pada Industri Manufaktur), Jurnal STIE Semarang, 9(1)

Apriliyanti, V., Hermi dan Herawati,V. (2019). Pengaruh Kebijakan utang, Kebijakan Dividen, Profitabilitas, Pertumbuhan Penjualan dan Kesempatan Investasi Terhadap Nilai dan Ukuran Perusahaan sebagai Variabel Moderasi, Jurnal Magister Akuntansi Trisakti, 6(2),

Brigham, E, F., and Houston, J, F. (2019). Dasar-Dasar Manajemen Keuangan, Edisi 14, Jakarta: Salemba Empat.

Dewi. (2015). Pengaruh Profitabilitas, Keputusan Investasi, Keputusan Pendanaan, Kebijakan Dividen dan Good Corporate Governance Terhadap Nilai Perusahaan (Studi Empiris Pada Perusahaan Non Keuangan yang Terdaftar di Bursa Efek Indonesia Pada Tahun 2010-2014). Yogyakarta: Jurnal Ekonomi dan Bisnis Indonesia.

Fahmi, I. (2014).Manajemen keuangan perusahaan dan pasar modal.Jakarta:Mitra Wacana Media.

Kushartono, R, C dan Nurhasanah, N (2017). Analisis Pengaruh Rasio Keuangan Terhadap Nilai Perusahaan Pada Perusahaan yang Tergabung Dalam Indeks LQ45 Periode 2010 2016, Jurnal Buana Ilmu, 2(1), 
Kurnia, D (2019). Profitabilitas, Kebijakan Dividen dan Harga Saham terhadap Nilai Perusahaan, Jurnal Akuntansi Kajian Ilmiah Akuntansi, 6(2),

Languju, O., Mangantar, M dan Tasik, H, H, D (2016). Pengaruh Return On Equity, Ukuran Perusahaan, Price Earning Ratio Dan Struktur Modal Terhadap Nilai Perusahaan Property and Real Estate Terdaftar Di Bursa Efek Indonesia, Jurnal Berkala Ilmiah Efisiensi, 16(2),

Lienandjaja, T. (2019). Mandiri Sekuritas Analyst. Focus Banking Sektor Update.

Manoppo, H dan Arie, F, F. (2016). Pengaruh stuktur Modal, Ukuran Perusahaan dan Profitabilitas Terhadap Nilai Perusahaan Otomotif yang Terdaftar di Bursa efek indonesia Periode 2011-2014. Manado: Jurnal EMBA, ISSN 2303-1174. Tahun 2016, $4(2)$,

Martin, T, K. (2014). Financial Management Principles an Applications, $12^{\text {th }}$. Pearson.

Misran, M., dan Chabachib, M (2017). Analisis Pengaruh DER CR dan TATO terhadap PBV dengan ROA sebagai Variabel Intervening (Studi Pada Perusahaan Properti Dan Real Estate yang terdaftar pada BEI Tahun 2011 - 2014), Diponegoro Journal Ofmanagement,6(1),

Nur'aidawati, S. (2013). Pengaruh Current Ratio (CR), Total Asset Turnover (TATO), Debt to Equity Ratio (DER) dan Return On Asset (ROA) terhadap Harga Saham dan Dampaknya pada Nilai Perusahaan, Jurnal Sekuritas, 1(3),

Nurhayati, M. (2013). Profitabilitas, likuiditas dan ukuran perusahaan pengaruhnya terhadap kebijakan dividend dan nilai perusahaan sektor non jasa. Jurnal Keuangan dan BisnisUniversitas Mercu Buana Jakarta, Jurnal keuangan dan bisnis, 5(2).

Pasando, V (2018). Pengaruh Debt to Assets Ratio, Total Assets Turn Over dan Return On Assets terhadap Price to Book Value pada Perusahaan sub sektor otomotif dan komponen yang terdaftar di Bursa Efek Indonesia, Jurnal Akuntansi STIE Sultan Agung, $4(2)$,

Putra, R, A. (2018). Pengaruh Profitabilitas terhadap Nilai Perusahaan dengan Harga Saham sebagai Variabel Intervening pada Perusahaan Property dan Real Estate di BEI,Jurnal Fakultas Ekonomi, 13(2).

Rahayu, M dan Sari, B. (2018). Faktor-Faktor yang Mempengaruhi Nilai Perusahaan,Jurnal Ikraith-Humaniora, 2(2),

Rinnaya, I, Y., Andini, R dan Oemar, A. (2016). Pengaruh Profitabilitas, Rasio Aktivitas, Keputusan Pendanaan keputusan Investasi Terhadap Nilai Perusahaan, Journal of Accounting, 2(2),

Ross, S, A., Westerfield, R, W., dan Jordon, B, D. (2015). Pengantar Keuangan Perusahaan, Edisi Global Asia, Jakarta: Salemba Empat. 
Rutin., Triyonowati dan Djawoto. (2019). Pengaruh Kinerja Keuangan terhadap Nilai Perusahaan dengan Kebijakan Dividen sebagai Variabel Moderating, Jurnal Riset Akuntansi dan Perpajakan 6(1),

Sari, S, N., Mardni, R, M dan Wahono, B (2019). Pengaruh Rasio Keuangan dan Return Saham pada Nilai Perusahaan Perdagangan Di BEI, Jurnal Ilmiah Riset Manajemen Unisma $8(3)$

Sondakh, P., Saerang, I dan Samadi, R (2019). Pengaruh Struktur Modal (ROA, ROE DAN DER) terhadap Nilai Perusahaan (PBV) pada Perusahaan Sektor Properti yang terdaftar di BEI (Periode 2013-2016), Jurnal Riset Ekonomi, Manajemen, Bisnis Dan Akuntansi, $2(3)$,

Sugiyono. (2016). Metode Penelitian Kuantitatif, kualitatif dan kombinasi (Mixed Method).Edisi 5. Bandung: Alfabeta, CV.

Sutrisno, W, A dan Yulianeu (2017). Pengaruh CR, DER dan TATO terhadap PBV Dengan ROA Sebagai Variabel Intervening (Studi Pada Perusahaan Property \& Real Estate yang terdaftar pada BEI Tahun 2010-2014), Journal Of Management, 3(3),

Utami, R, B dan Prasetiono. (2017). Analisis Pengaruh TATO, WCTO, dan DER Terhadap Nilai Perusahaan dengan ROA sebagai variabel intervening, Diponegoro Jurnal of Management,5(2),

, P dan Welas. (2019). Pengaruh Current Ratio, Return On Asset, Total Asset Turnover Dan Debt To Equity Ratio terhadap Nilai Perusahaan, Jurnal Akutansi dan Keuangan,8(1),

Utomo, N, A. (2016). Faktor-Faktor Yang Mempengaruhi Nilai Perusahaan Pada Perusahaan Indeks LQ45 di Bursa Efek Indonesia, Jurnal Dinamika Akuntansi, Keuangan dan Perbankan, 5(1),

Widodo, A (2018). Analisis Pengaruh CR, TATO, dan DAR terhadap ROA, Serta Dampaknya terhadap Nilai Perusahaan, Jurnal Ilmiah Manajemen Forkamma, 1(2)

Winarno, W, W. (2015). Analisis Ekonometrika dan Statistika dengan Eviews Edisi 4. Yogyakarta: UPP STIM YKPN.

https://industri.kontan.co.id/news/gapmmi-memperkirakan-industri-makanan-dan-minumanakan-naikkan-harga-3-5

https://industri.kontan.co.id/news/tantangan-bagi-industri-makanan-dan-minuman-di-tahunini

https://industri.kontan.co.id/news/industri-makanan-dan-minuman-akan-tumbuh-8-9-tahun-ini

https://industri.kontan.co.id/news/nilai-tukar-melemah-industri-makanan-dan-minuman-siapkerek-harga-jual 